Pierre Singer Jonathan Cohen

\section{Nutrition in the ICU: proof of the pudding is in the tasting}

Received: 27 October 2014

Accepted: 27 October 2014

Published online: 29 November 2014

(C) Springer-Verlag Berlin Heidelberg and ESICM 2014

P. Singer $(\bowtie) \cdot J$. Cohen

Department of General Intensive Care and Institute for Nutrition Research, Rabin Medical Center, Beilinson Hospital, Sackler School of Medicine, Tel Aviv University, 49100 Petah Tikva, Israel e-mail: psinger@clalit.org.il

Tel.: +97239376521

The ICU nutrition support paradigms establishing an obligatory link between calories and protein administration [1] have been challenged in the past decade. Current guidelines regarding nutritional support in the ICU are mainly based on physiological statements [2]. While large audits including thousands of patients worldwide have shown that in daily practice, calorie and protein administration are well below current recommendations, varying between 1,200 and $1,450 \mathrm{kcal} /$ day and $0.5-0.8 \mathrm{~g} /$ $\mathrm{kg} /$ day of protein [3], strong evidence regarding optimal energy and protein requirements as well as nutrient choices in various ICU conditions is not yet available. Most recent large trials focusing on one specific element of nutritional support, such as increased calories and/or protein, the use of supplemental parenteral nutrition, or high dose pharmaco-nutrients, have given confusing signals, failing to demonstrate any strong advantage [4-9]. This may leave the impression that most of the recommendations based on physiology do not lead to improved outcomes. However, most of these studies are characterized by large gaps between prescribed and administered protein-calorie intake, and in fact the intended targets, whether calories or protein, are seldom achieved. Figure 1 shows the actual amount of calories received by the patients in these various trials. These findings confirm the very frequent occurrence of underfeeding and so cannot be expected to answer any specific nutrition-related questions. In addition, the studies have not been stratified according to age, presence, and severity of malnutrition/ obesity or timing of administration. What is required are studies comparing outcomes of patients receiving a nutrition regimen according to guidelines with the "facts on the ground" [10], i.e., low calorie and protein intakes, for instance those derived from the Nutrition Day ICU audits. No true conclusions or strong recommendations will be possible without this step.

The recently published study by Ekpe et al. [11] stresses once again the importance of achieving appropriate energy goals. The study, which investigated the impact of energy deficits on the microbiological results of blood cultures of long-term severely ill mechanical ventilation patients, confirms previous publications associating large energy deficits with infectious complications [12]. Interestingly, the cumulated energy deficits for patients developing methicillin-resistant Staphylococcus aureus blood stream infections (MRSA-BSI) were greater $(>-300 \mathrm{kcal} /$ day more) than those with ICU BSI caused by other pathogens. Host-nutrient availability of nitrogen-dependent regulation may explain the specific effects of MRSA-BSI prevention. The limitations of this study are the use of an equation rather than direct measurement of resting energy expenditure by indirect calorimetry to target calories, despite the fact that this equation has been validated for this specific local patient population. Most of the equations have shown poor accuracy and this equation should always be validated locally before using. In addition, the studied patients were severely undernourished, reaching a daily negative energy balance of $-1,000$ to $-1,300 \mathrm{kcal}$. Unfortunately, the authors do not detail the degree of the nitrogen gap, which may be even more deleterious. While 
Figure 1 represents the energy administered to critically ill patients in various studies [4-9] compared to the recommendations [2] that suggest $25 \mathrm{kcal} / \mathrm{kg} / \mathrm{day}$ (most of the studies reported mean weight of $77 \mathrm{~kg}$ in their population)

\section{Recommendations based on $25 \mathrm{kcal} / \mathrm{kg} /$ day for an adult weighting $77 \mathrm{~kg}$}

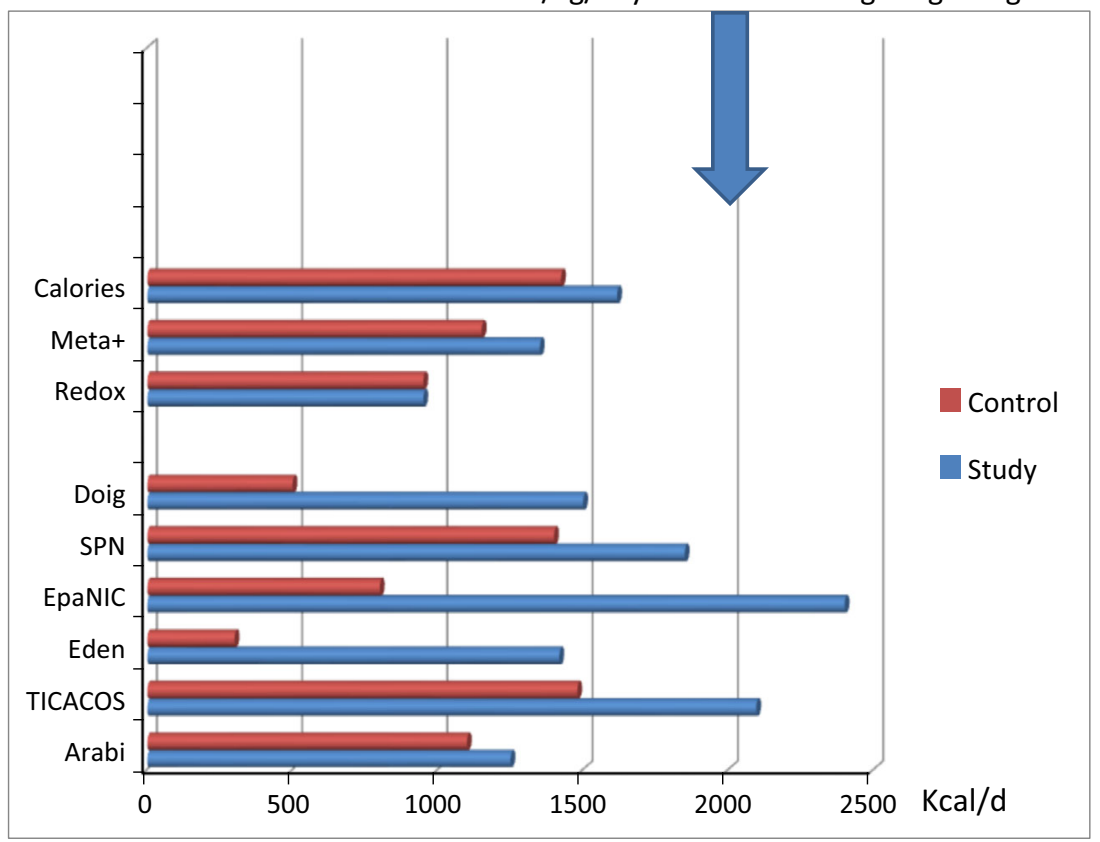

limiting energy deficits may decrease the infection rate, giving excessive amounts of calories may also increase infection rates [4]. We therefore need to aim for more finetuning when prescribing nutritional support.

One of the main goals in intensive care is to provide oxygen and nutrients to the cell to avoid cell necrosis. Cell nutrient utilization, however, remains a black box. Administered macronutrients can be stored, like most of the lipids, or largely oxidized, like carbohydrates. Most of the studies leading to recommendations regarding the ideal administration of protein are based on nitrogen balance studies. In stress, protein synthesis is increased but less than protein degradation. The substrates we are administrating may be harmful at the onset of ischemia reperfusion, inhibiting autophagy [13], but could also be helpful in limiting the critical decrease of cell ATP [14], preventing programmed cell death or resolving inflammatory processes, for example, $n-3$ fatty acids producing lipoxin and resolvin [15]. While nutrition may never be the magic bullet to cure critical illness, improved understanding and its skilled use may improve cell metabolism, thus allowing the organism to better cope with injury.

Future studies should therefore take into consideration the following: (1) whether calorie targets were planned according to indirect calorimetry rather than predictive equations, which are misleading in 50-60\% of the cases; (2) whether protein administration meets recommendations; (3) whether age or obesity, body composition, and the ICU condition (resuscitation, stabilization, recovery, chronically critically ill) were taken into account; and (4) whether there was wise use of specific nutrients related to the specific needs of the patient and not to a general statement. The aim is to provide a more personalized nutritional prescription that may allow the amelioration of the patient condition. The time has come to use a universal control regimen to test specific calorie and/or protein intake as well as special nutrients on a large scale.

Conflicts of interest The authors have no conflict of interest to report in relation to this manuscript.

\section{References}

1. Elwyn DH (1980) The influence of caloric and protein intake upon nitrogen balance. Crit Care Med 9:9-20

2. Singer P, Berger MM, Van den Berghe G, Biolo G, Philip Calder P, Forbes A, Griffiths R, Kreyman G, Leverve X, Pichard C (2009) ESPEN guidelines on parenteral nutrition: intensive care. Clin Nutr. 33:387-400
3. Alberda C, Gramlich L, Jones N, Jeejeebhoy K, Day AG, Dhaliwal R, Heyland DK (2009) The relationship between nutritional intake and clinical outcomes in critically ill patients: results of an international multicenter observational study. Intensive Care Med 35:1728-1737
4. Singer P, Pichard C (2013) Reconciling divergent results on the latest parenteral nutrition studies in the ICU. Curr Opin Clin Nut Metab 16:187-193 
5. Heyland D, Muscedere J, Wischmeyer PE, Cook D, Jones G, Albert M, Elke G, Berger MM, Day AG, Canadian Critical Care Trials Group (2013) A randomized trial of glutamine and antioxidants in critically ill patients. N Eng J Med 368:1489-1497

6. van Zanten AR, Sztark F, Kaisers UX, Zielmann S, Felbinger TW, Sablotzki AR, De Waele JJ, Timsit JF, Honing ML, Keh D, Vincent JL, Zazzo JF, Fijn HB, Petit L, Preiser JC, van Horssen PJ, Hofman Z (2014) High-protein enteral nutrition enriched with immunemodulating nutrients vs standard highprotein enteral nutrition and nosocomial infections in the ICU: a randomized clinical trial. JAMA 312:514-524

7. Rice TW, Wheeler AP, Thompson BT, Steingrub J, Hite RD, Moss M, Morris A, Dong N, Rock P, National Heart, Lung, and Blood Institute Acute Respiratory Distress Syndrome (ARDS) Clinical Trials Network (2012) Initial trophic vs full enteral feeding in patients with acute lung injury: the EDEN randomized trial. JAMA 307:795-803
8. Rice TW, Wheeler AP, Thompson BT, de Boisblanc BP, Steingrub J, Rock P (2011) NIH NHLBI acute respiratory distress syndrome network of investigators: enteral omega-3 fatty acid, gamma-linolenic acid, and antioxidant supplementation in acute lung injury. JAMA 306(14):1574-1581

9. Arabi YM, Tamim HM, Dhar GS, AlDawood A, Al-Sultan M, Sakkijha MH, Kahoul SH, Brits R (2011) Permissive underfeeding and intensive insulin therapy in critically ill patients: a randomized controlled trial. Am J Clin Nutr 93(3):569-577

10. Singer P, Doig G, Pichard P (2014) The truth about ICU nutrition. Intensive Care Med 40:252-255

11. Ekpe K, Novara A, Mainardi JL, Fagon JY, Faisy C (2014) Methicillin-resistant Staphylococcus aureus bloodstream infections are associated with a higher energy deficit than other ICU-acquired bacteremia. Intensive Care Med 40:1878-1887. doi:10.1007/s00134014-3502-6
12. Rubinson L, Diette GB, Song X, Brower RG, Krishnan JA (2004) Low caloric intake is associated with nosocomial bloodstream infections in patients in the medical intensive care unit. Crit Care Med 32:350-357

13. Wellen KE, Thompson CB (2010) Cellular metabolic stress: considering how cells respond to nutrient excess. Mol Cell 40:323-332

14. Serhan CN (2014) Pro-resolving lipid mediators are leads for resolution physiology. Nature 510(7503):92-101

15. Galluzzi L, Bravo-San Pedro JM, Vitale I, Aaronson SA, Abrams JM, Adam D, Alnemri ES et al (2014) Essential versus accessory aspects of cell death: recommendations of the NCCD 2015. Cell Death Differ 1-16. doi: 10.1038/cdd.2014.137 